\section{A TECHNOLÓGIAI FEJLŐDÉS ÉS A FOGYASZTÓI ELVÁRÁSOK FOLYAMATOS VÁLTOZÁSRA KÉNYSZERÍTENEK INTERJÚ SZTANÓ IMRÉVEL}

Lambert Gábor (Magyar Biztositók Szövetsége), gaborlambert@mabisz.hu

\section{ÖSSZEFOGLALO}

Sztanó Imre az NN Biztosító magyarországi elnök-vezérigazgatói posztja után 2020 elejétől a holland NN csoport nemzetközi digitalizációs igazgatójaként (Chief Digital Officer) tevékenykedik. A társaság törekvéseit és eredményeit a magyar NN Biztosító példáin keresztül mutatta be.

A mostani interjú a Covid-19 járvány kitörése előtt készült.

\section{SUMMARY}

Imre Sztanó after holding the post of CEO of NN Hungary, from the beginning of 2020 he acts as Chief Digital Officer of NN Group. The intentions and results of the company are presented by using the example of the Hungarian NN insurance company.

The present interview was done before the outbreak of Covid-19 pandemic.

\section{Kulcsszavak: agilis működés, biztosítás, digitalizáció}

Key words: agile operation, digitalization, insurance

JEL: G22, O30

DOI: $10.18530 /$ BK.2020.1-2.6

http://dx.doi.org/10.18530/BK.2020.1-2.6
A magyarországi NN tavaly a hazai pénzügyi szektorban elsőként állt át teljes szervezetével az agilis müködésre. Ez a szervezeti modell általános az NN-en belül, vagy az Önöké a kivétel?

Az agilis működés nemcsak a magyarországi leányvállalatra jellemző, de az NN magyarországi csapata volt az első a cégcsoporton belül, akik belefogtak a szervezeti szintủ agilis átalakulásba. Hasonló, teljes szervezeti váltásba fogott bele a spanyol cégünk is, és több NN-es ország is megvalósította az agilis modell egyes részelemeit. Az egész folyamat oda vezethető vissza, hogy meggyőződésünk szerint egyszerre több dolog kell ahhoz, hogy a változó ügyféligényeknek sikeresen meg tudjunk felelni. Kell egy kitűzött üzleti stratégia, kellenek a technológiai fejlesztések, de legalább ennyire kell egy szervezet is, amelyik képes folyamatosan fejlődni és valóban értéket teremteni az ügyfeleknek.

Ha jól értem, az agilis szervezet lényege az, hogy kis, dinamikus egységek, amelyek a saját területükön teljes felelösséget vállalnak a müködésükért, próbálnak hatékonyan együttmüködni.

Ez egy dimenziója az agilis szervezeti müködésnek, amelynek az is fontos jellemzője, hogy próbál erőteljesen az ügyféligényekre és az értékteremtésre koncentrálni. Ezért az agilisban nem is csillagháborús projektekben gondolkozunk, hanem azt nézzük, hogy mi az a legkisebb egység, ami már értéket teremthet az ügyfélnek. Ez nemcsak azért fontos, hogy minél hamarabb legyen eredmény, de minél előbb hozunk a piacra valamilyen újítást, annál gyorsabban lesz visszajelzés arról, hogy ez az ügyfélnek értéket teremt-e vagy sem. A legfontosabb az agilis szemléletben, hogy jellegéből adódóan sokkal inkább képessé tesz a folyamatos tanulásra és változtatásra, ami ebben az - ügyfélelvárásaiban és technológiájában is elképesztő sebességgel változó - világban elengedhetetlen.

Hogyan illeszkedik ebbe a csoporton belül erősödő szervezeti logikába egy digitális igazgatói poszt, amely szintről azért mégiscsak csillagháborús léptékben kell tervezni?

Nagyon fontos feladat a vízió megalkotása arról, hogy merre akarunk menni, de legalább ennyire fontos a megvalósítás minősége is. A tapasztalatok azt mutatják, hogy a digitális transzformációk jelentős része nem teljes mértékben hozza meg az elvárt eredményt. Bármilyen jó is a stratégiai irány, biztos, hogy egy ilyen út sok buktatóval, tapasztalással és utánigazítással jár. Ezért is annyira fontos, hogy folyamatosan tanuló szervezetet építsünk fel. E tekintetben nincs különbség abban, hogy egy helyi vagy nemzetközi szervezetben ülünk.

Nemzetközi digitális igazgatóként elsősorban az élet üzletágban keresi majd az új megoldásokat?

Mi egyáltalán nem gondolkodunk ilyen szempontból élet és nem-élet kategóriában, hiszen az ügyfelek sem így gondolkodnak. Nagy többségüknek ezek a fogalmak semmit sem jelentenek, nekik megoldandó feladataik, aggodalmaik vannak, szeretnék biztonságban 
tudni a szeretteiket, a saját egészségüket vagy akár vagyontárgyaikat. Mi ezekre az igényekre szeretnénk válaszokat hozni, és itt jön a képbe a digitális igazgatói funkció. Az elmúlt években óriási változás állt be a technológiai lehetőségek által. Egyrészt a technológia formálja is az ügyféligényeket, másrészt rengeteg új lehetőséget ad a változó igények megválaszolására.

Az, hogy a magyar NN aktiválja a nem-élet üzletágát, az egész csoportra jellemző, vagy csak magyar sajátosság?

Vegyes a kép, hiszen már vannak olyan leányvállalataink, amelyek hosszabb-rövidebb ideje kompozit biztosítóként múködnek. Az adott piacainkon, így Magyarországon is folyamatosan azt vizsgáljuk, hogy mi a következö logikus lépés annak érdekében, hogy még relevánsabbak legyünk. Mi egyértelműen azt láttuk, hogy a nem-élet üzletág újabb lehetőség arra, hogy több módon tudjunk ügyfeleket megszólítani, több igényükre tudjunk választ adni.

A kinevezéséről kiadott rövid közlemény feladatként jelölte meg az új partnerségek kialakítását is. Ez pontosan mit jelent: startupok bevonását az NN müködésébe, vagy ökoszisztémák kialakítását, más ágazatokkal való együttműködés kiépítését?

Bármelyiket jelentheti, mert azt gondoljuk, ahhoz, hogy az ügyféligényeknek folyamatosan meg tudjunk felelni, innovációra van szükség, és nem akarjuk korlátozni azt, hogy ez milyen forrásból származzon. Szerintem ebbe egyre inkább beletartozik az is, hogy partneri kapcsolatban tudunk ügyféligényekre választ adni. Vagyis szeretnénk innoválni házon belül is, de egyáltalán nem gondoljuk azt, hogy feltétlenül mi tudunk mindenre választ adni. Szeretnénk olyan partnerekkel dolgozni, akik mind értékrendjükben, mind az általuk kínált szolgáltatások színvonalában hasonlatosak az NN-hez, és képesek értéket teremteni az ügyfélnek.

Miért pont a bejelentett termékekre koncentrál az NN a nem-élet ágban, és miért maradnak ki a hazai piacon ugyancsak prosperáló gépjármü-biztosítások?

A lakásbiztosítás gyakorlatilag természetes választás volt, mert egy ügyfél életében a család és az egészség mellett az otthon az egyik legfontosabb érték. Ezáltal a lakásbiztosítás nagyon jól kapcsolódik ahhoz az öngondoskodási palettához, amit eddig is kínáltunk Magyarországon. Ezt erősítik azok a piaci változások is, amelyeknek a tanúi vagyunk, hiszen a Nemzeti Bank kihozta a Minősített Fogyasztóbarát Otthonbiztosítás koncepciót, és azt gondoljuk, hogy ez az NN-nek nagyon jó belépési pont lehet.

Emellett még két termékcsoporttal jelentkezünk. Egyrészt a hitelfedezeti biztosításokkal, ami abból adódott, hogy több olyan partnert látunk magunk körül, akikkel ezen termék vonatkozásában jól együtt tudnánk működni. Másrészt pedig az utasbiztosítást hozzuk be Magyarországon, mert ez megint csak egy olyan jól definiálható ügyféligényt jelent, amin keresztül sok-sok ügyfelet szólíthatunk meg. Mint azt a decemberi sajtótájékoztatón is hangsúlyoztuk, mindez nem azt jelenti, hogy itt feltétlenül megállunk, de jelenleg ennyi új terméktípus szerepel a már jóváhagyott terveinkben.
Hogy ítéli meg, hol tart a hazai biztosítási szektor digitalizációja nemzetközi viszonylatban?

Szerintem elsősorban nem a nemzetközi összehasonlítás érdekes, mert az ügyfelek sem így gondolkoznak. Relevánsabbnak érzem azt, hogy az ügyféligények változása átível a szektorokon. Ha az ember bizonyos újításokat vagy ügyfélélményt megtapasztal egy szektorban, akkor hajlamos ugyanezeket elvárni minden más területen is. Ezt a jelenséget pedig egyik ágazat sem hagyhatja figyelmen kívül, és ebben a mi szektorunknak is van bőven teendője.

\section{Mit jelent ez az NN-nél a gyakorlatban?}

Az első dolog, ami ehhez kötődik, hogy a mindennapi müködést digitalizáljuk és automatizáljuk. Nem véletlen, hogy az NN-nél mi is az értékesítés digitalizációjával kezdtünk Magyarországon, mert azt gondoltuk, hogy ez az, ami a legközvetlenebbül érzékelhető lesz az ügyfeleink számára. Teljesen papírmentessé tettük az értékesítési folyamatot, bevezettük az elektronikus aláírást, és automatizáltuk a kockázatelbírálást. Utóbbinál korábban az ajánlat befogadása és a kötvény kibocsátása között az átfutás tizenhárom nap volt. Az automatizációval ez bizonyos esetekben akár tíz percre is le tud menni. Ha mondjuk az ajánlat beküldése után meghívjuk az ügyfelet egy kávéra, mire megissza, a kötvény már ott is van az e-mail fiókjában. Ez gyökeresen más ügyfél- és partnerélményt jelent, és ugyanezt a célt szolgálja a többi digitalizációs fejlesztésünk is.

Persze a mindennapi működés digitalizálása csak egyik része a dolognak. Legalább ennyire fontos az, hogy hogyan szólítjuk meg új módon az ügyfeleket. Miként az sok fórumon elhangzik: kevesen ébrednek azzal, hogy biztosítást akarnak vásárolni. Az ügyféligény az, hogy elkezdek megoldást keresni egy engem foglalkoztató téma kapcsán, legyen az az egészségemmel, családommal, hobbimmal vagy éppen élethelyzettel kapcsolatos. Ezekben az - egyéként jellemzően digitális - interakciókban szeretnénk részt venni, ahol a beszélgetés nem onnan indul, hogy vegyél egy biztosítást. Példa erre a runaddict applikációnk, ahol a futók számukra igazán releváns dolgokhoz tudnak hozzájutni, mint például az orvosi call center, segítség a versenyekre való felkészülésben vagy éppen diszkont a futófelszerelések árából.

Eljuthat az értékesítés digitalizációja odáig, hogy az értékesítő ki is marad a folyamatból?

$\mathrm{Az}$ egészen kis összegű életbiztosítások kivételével én ezt nem gondolom. Az életbiztosítás belátható ideig igényelni fogja a személyes hitelességet, hiszen ezek nagy döntések az ember életében, ahol a többségünk szeretne egy hús-vér arcot látni, akiben szakmailag és emberileg is megbízhat. Ezzel együtt a személyes értékesítés nem ugyanazt fogja jelenteni, mint ma, teljesen át fogja szőni a technológia. Az egyszerűbb tranzakciók az ügyfélkiszolgálásban teljesen digitális csatornákra fognak terelődni. A hitelességet és tanácsadást igénylő beszélgetések esetében véleményem szerint döntő 
többségében meg fog maradni a személyes értékesítő, ugyanakkor ez sem feltétlenül fizikai találkozás formájában fog megvalósulni. Szerintem a szolgáltatók kiemelt feladata, hogy akármilyen csatornán is kerül velük kapcsolatba az ügyfél, ugyanazt a magas szintű kiszolgálást nyújtsák.

A személyre szabott biztosításoké a jövő? Ha igen, akkor mi marad a hagyományos biztosítási alapelvből: képezzünk minél nagyobb kockázatközösséget, és így porlasszuk szét a díjakat a csaknem mindenki számára megfizethető nagyságrendekig?

Ez sokrétủ kérdés, és egyáltalán nem egyszerủ a válasz. Szerintem az ügyfeleknek a személyesség érzését mindenképpen meg kell kapniuk. Érezniük kell, hogy az ő igényeikre, élethelyzetükre, számukra fontos dologra kapnak választ. Olyan szempontból is a személyesség irányába megyünk el szerintem, hogy a megelőzés egyre fontosabbá válik a biztosításban is, és ezzel összefüggésben a személyes árazás is meg tud jelenni. Ez az árazás a gyakorlatban nem konkrétan az adott személyre vonatkozik, de az, hogy egyre több adat keletkezik rólunk, és ezt megosztjuk a szolgáltatónkkal, befolyásolni fogja az árazást.

Az árazást így befolyásolni tudja például az életmódunk is. Ha diabéteszesként a vércukorszintemet az adott sávban tartom, és ezt megosztom a szolgáltatóval, akkor jobb kockázati besorolásba kerülhetek, és kedvezőbb biztosítási díjat fizethetek. Ezáltal egy újabb dimenzióval töltődik fel a biztosítások társadalmi szerepe, és ha a szektor ezt jól fogja meg, az pozitív erőt képezhet a társadalomban. Nyilvánvalóan nagyon fontos a felelössége a szektornak abban, hogy ezt olyan módon tegye meg, hogy a társadalmi felelősségvállalás és a kockázatközösség szelleme fenn tudjon maradni, és ne legyen ennek a folyamatnak kivető hatása.

Egy másik trend, a shared economy terjedése, vagyis a tulajdonlás szerepének és a tulajdonérzet fontosságának a csökkenése hogyan fog hatni a biztosításokra?

Az biztosan látszik, hogy erősödik ez a trend, és az új generációk már másképpen állnak a tulajdonláshoz, mint elődeik. Ezzel együtt is számos nyitott kérdés van még abban a vonatkozásban, hogy milyen sebességgel és az élet mely területein fog elterjedni ez a jelenség. Nyilván nem minden részét fogja érinteni az életnek, de egyértelműen hat a biztosításokra és arra is, hogy valójában kinek a tulajdonát és milyen konstrukcióban biztosítjuk ebben az új felfogásban. Szerintem ez egy további motiváció arra, hogy partnerségekben tevékenykedjünk, mert valószínűleg így jobban tudunk erre a változásra választ adni.

Az európai szabályozás mennyiben követi az említett ügyféligények közül azt, hogy a fogyasztó elsősorban könnyen átlátható termékeket és gyors ügyintézést vár el?

Szerintem ez folyamatos útkeresés. Mi az a szint, ahol tényleg teljes körü információt tudunk adni az ügyfélnek, fel tudjuk tárni az igényét, és valóban igényalapon tudunk neki értékesíteni, de közben ne zúdítsunk rá túl nagy információdömpinget, ami gátolhatja a tisztánlátást. Nem gondolom, hogy könnyen meg lehet találni ebben az optimális egyensúlyt, de biztos vagyok abban, hogy Magyarországon ezt a dilemmát pontosan látja a felügyelet is

Nem magától értetődő tehát, hogy a digitalizáció kikényszeríti az egyszerüsítés, a simplicity irányába való haladást?

Olyan szinten fejlődnek a technológia adta lehetőségek, így az is, hogy az ügyfelek elött mekkora tér nyílik, és milyen veszélyeknek vannak kitéve, hogy ez szüntelen dialógust és utánkövetést igényel. Ebben a folyamatban nem látom a végpontot, amikor befejezettségről beszélhetnénk. Visszautalva a beszélgetés elejére, mindez nagyfokú agilitást igényel mind szolgáltatói, mind szabályozói oldalon. 